\title{
The Dynamics of Subjective Career Success: A Qualitative Inquiry
}

\author{
Leon Hupkens*D, Jos Akkermans (D), Omar Solinger (D) and Svetlana Khapova \\ Department of Management \& Organization, School of Business and Economics, Vrije Universiteit Amsterdam, \\ 1081 HV Amsterdam, The Netherlands; j.akkermans@vu.nl (J.A.); o.n.solinger@vu.nl (O.S.); \\ s.n.khapova@vu.nl (S.K.) \\ * Correspondence: 1.hupkens@vu.nl
}

Citation: Hupkens, L.; Akkermans,

J.; Solinger, O.; Khapova, S. The Dynamics of Subjective Career Success: A Qualitative Inquiry. Sustainability 2021, 13, 7638. https:// doi.org/10.3390/su13147638

Academic Editor: Annet de Lange

Received: 5 May 2021

Accepted: 3 July 2021

Published: 8 July 2021

Publisher's Note: MDPI stays neutral with regard to jurisdictional claims in published maps and institutional affiliations.

Copyright: (C) 2021 by the authors. Licensee MDPI, Basel, Switzerland. This article is an open access article distributed under the terms and conditions of the Creative Commons Attribution (CC BY) license (https:// creativecommons.org/licenses/by/ $4.0 /)$.

\begin{abstract}
Current perspectives on career success have yet to show whether and how subjective career success evaluations may change over time and across career phases. By adopting a retrospective life-span approach to careers, our qualitative inquiry into the career experiences of 63 professionals contributes to the temporal understanding of subjective career success by exploring patterns in how subjective career success perceptions and priorities may change over time. The temporal development of subjective career success was explored among early-career, mid-career, and late-career workers by piecing together retrospective evaluations of career success perceptions. Our findings point to common patterns in career success perceptions across the lifespan. Specifically, we found five shift components of career success perceptions during people's careers: (1) quitting striving for financial success and recognition; (2) an increased focus on personal development across the career; (3) a stronger emphasis on work-life balance across the career; (4) a shift toward being of service to others; and (5) no change in subjective career success components across the career. These patterns reflect ways in which workers engage in motivational self-regulation and the corresponding career goal-setting across the lifespan. The theoretical implications are discussed.
\end{abstract}

Keywords: subjective career success; career development; career phases; motivational theory of lifespan development; socio-emotional selectivity theory; motivational self-regulation; future time perspective

\section{Introduction}

Change and development over time is central to our understanding of careers. Broadly, a career can be defined as "the unfolding sequence of a person's work experiences over time" [1]. Many career theories, such as the career development theory [2], life stage theory [3], and the kaleidoscope career [4] explicitly address the role of time, in the form of career phases and stages, in explaining how individual careers evolve. Yet, this focus on temporal shifts is much less prominent in recent studies, which have focused on the outcome of a career: career success [5]. Career success is typically conceptualized from two different perspectives: objective career success (OCS) and subjective career success (SCS) [6]. OCS focuses on directly observable criteria, such as someone's salary and number of promotions, whereas SCS refers to an individual's perception of achieving meaningful career outcomes [7-9], such as (sustainable) employability [10,11]. For many decades, OCS was the key criterion of career success. Yet, with the emergence of more volatile environments, flexible careers and increased interorganizational mobility, the research focus has shifted to SCS indicators, most notably in terms of career satisfaction $[6,12]$. We define SCS as "the focal career actor's evaluation and experience of achieving personally meaningful career outcomes" [6] (p. 36) and investigate how these subjective evaluations change over the course of one's career. Surprisingly little research attention has been given to the notion of time in relation to career success [5]. More specifically, how individual evaluations of career success change over time, why the subjective evaluations evolve over time, and in which directions remains unclear [9]. Studying how SCS perceptions change 
over time is important, because it provides us with a new perspective on motivational self-regulation across the life span of a career [13] and what factors play a role in this ongoing process of achieving and maintaining congruence (e.g., $[2,14]$ ) between personal preferences and abilities and the career environment.

In this study, we explore how perceptions of and priorities in subjective career success aspects may change over the course of a career and how these perceptions relate to motivational self-regulation. Specifically, we analyze career narratives to enrich our current understanding of the developmental nature of SCS, answering the research question: "How does subjective career success develop over time?". In their review, Akkermans and Kubasch conclude that the field of careers research is skewed toward quantitative studies and call for more qualitative studies [12]. Considering career success specifically, Heslin suggests to take a qualitative approach to allow for the opportunity to uncover unique facets of career success [15]. This is complemented by Arthur and colleagues, who suggest more qualitative work on career success to study the richness of personal experiences of career success [5]. In their recent work, Shockley and colleagues have answered the call for more qualitative perspectives on career success [9]. We build upon this work and follow the suggestions to use a qualitative approach to allow for interpretations of subjective career success at the respondent level in studying the research question.

With this study, we aim to make two significant contributions to the career literature. First, we examine whether SCS perceptions can change over the course of a career $[9,16]$. Second, we investigate how, through motivational self-regulation and the time perspective, workers develop optimal conceptions of career success. We do this by investigating how motivational theory of life-span development [13], future time perspective [17], and workrelated motives [18] can enhance our understanding of patterns in SCS perceptions, for example, through a process of goal selection and goal domain prioritization over the course of a career.

\section{Theoretical Framework}

Career success is a key career research topic [12] and is commonly defined as an "accomplishment of desirable work-related outcomes at any point in a person's work experiences over time" [5] (p. 179). Career success encompasses both objective and subjective career outcomes [19], the former being commonly operationalized as salary, salary growth, and a position in a social status hierarchy [20] and the latter being operationalized as the individual's evaluation of his or her objective achievements [21]. We follow the argument of Shockley and colleagues [9] that current definitions of subjective career success suggest that (1) individuals create a subjective evaluation of their career success and (2) that subjective evaluation is required for additional aspects of career success that go beyond objective aspects, concluding that subjective career success is best defined as "driven by objective factors in addition to those that are less tangible in nature and require subjective interpretation" [9] (p. 129).

Research on the topic of SCS has been increasing in recent years [6], mostly utilizing career satisfaction [22] as a central aspect of SCS. Following recent calls for more construct differentiation of SCS (e.g., [15]), multidimensional operationalizations of subjective career success have been developed [9,16]. In their Cross-Cultural Collaboration on Contemporary Careers (5C), Mayrhofer and colleagues [16] studied conceptualizations of career success across 16 different nations, converging on seven aspects of career success: financial security, financial success, learning and development, work-life balance, positive relationships, positive impact, and entrepreneurship, which follow under four themes: material concerns, learning, social relations, and pursuing one's own projects. The work of Shockley and colleagues [9] complements the findings from the $5 \mathrm{C}$ project by providing additional aspects to the conceptualization of subjective career success aspects by specifically studying the conceptualization of career success by people in different career contexts. Taken together, both studies provide a foundational conceptualization to subjective career success. In order 
to use the SCS aspects of the two perspectives in our study, we closely examined both studies connecting their components (see Appendix B for an overview).

The first aspect is labelled autonomy, which is characterized by personal ownership of one's career, being self-reliant, and feeling 'in charge' of one's career $[9,16,23]$. The importance of setting up new projects and enterprises are common examples of this entrepreneurial aspect of SCS. Autonomy is conceptualized as an overall sense of personal accomplishment, in which resources from the work environment are utilized [16]. An example item is: "I feel my career is successful when I have developed and been responsible for my own projects."

Knowledge striving is a key component of SCS $[9,16,24]$ and is represented in the second aspect, personal development. A central goal of this aspect of SCS is the attainment of knowledge and skills not only for the sake of knowing, but also out of the urgency to 'stay current' in the occupational field one engages in [9]. This need to 'stay current' refers to one's need to maintain and expand skillsets to improve work performance. Learning involves both formal learning, the attainment of skills through formal education, and continuous informal learning on the job and from significant life experiences [16]. An example item is: "I feel my career is successful when I have expanded my skill sets to perform better."

Influence as the third SCS aspect revolves around the importance of being able to have an impact on an organization or its members. It involves taking pride in seeing the effects of personal influence. Feeling that one contributes is an essential component of influence: "I had an important contribution to the whole organization, which impacts people every day" [9] (p. 139). Influence reflects a sense of power over and impact on the organizational and social environment. An example item is: "I feel my career is successful when decisions that I have made have impacted my organization."

The concept of meaningful work has received broad interest [25] and operationalizations [26] and is represented as the fourth aspect of SCS, labeled service to others. In the context of career success, meaningful work is best translated as service to others and is typified by work that is personally or socially valued, "A person is successful if he or she feels that the career [is] a calling, that they are contributing to something larger than themselves" [9] (p. 139). An example item is: "I feel my career is successful when I believe my work has made a difference."

The importance of finding a balance between work and non-work commitments is captured in the fifth aspect, work-life balance. Being able to mentally, emotionally, and physically detach from work plays an important role in recovery from work-related strain [27]. In the context of career success, work-life balance can be viewed as an important outcome in cases where both the work and non-work domains require significant effort and attention (e.g., in dual career commuter couples). Work-life balance describes a successful career as a career in which sufficient time and energy is available for non-work commitments (e.g., quality non-work relationships) [9,16]. An example item is: "I feel my career is successful when I have been able to be a good employee while maintaining quality non-work relationships."

The sixth aspect is focused on work-context specific performances and outcomes and is referred to as quality work [9]. For example, the creation of a high-quality product or excellent levels of service in a profession can be essential aspects to career success. In comparison to the aspect of influence, quality work is about what one delivers to others (e.g., customers and clients) in the name of the employing organization, while influence is about the direct impact one has within the employing organization. With a high level of quality work fulfillment, work performances influence one's visibility within the organization [9]. An example item is: "I feel my career is successful when I am proud of the quality of the work I have produced."

Recognition links to the social context of an individual's SCS and embodies the seventh SCS aspect. Recognition is related to one's social status and reputation and concerns 
appreciation, receiving respect, and self-esteem [9]. An example item is: "I feel my career is successful when I have been recognized for my contributions."

The eight aspect, career satisfaction, has been the most dominant way of operationalizing SCS in the past [28], as it has been previously thought to capture the entire subjective evaluation. An example item is: "I feel my career is successful when my career is personally satisfying." Our recent studies in $[9,16]$ show how career satisfaction remains an important aspect of SCS but is complemented by the other aspects in this study.

The next two aspects, number nine and ten, concern one's career evaluation in relation to money and are referred to as financial security and financial success. Financial security refers the ability to provide for the basic necessities for living (e.g., "I feel my career is successful when I have been able to provide the basic necessities for living") and is to be distinguished from financial success, which is characterized by the ability to progressively acquire a level of comfort and social status over the course of the career [16] (e.g., "I feel my career is successful when I have been able to progressively make more money"). Pro-active work behaviors have been indicated as antecedents of financial success in recent work from the 5C research project [29]. SCS aspects are also reflected in the findings reported as "financial factors" and "advancement" [9].

The eleventh aspect of SCS is labelled positive relationships and refers to career success that revolves around the extent and quality of the engagement one has with their social environment and the importance that is put on the relationships one has in their career context. An example item is: "I feel my career is successful when I get along well with my colleagues." Positive relationships are also reflected in the findings reported by Shockley and colleagues as "relationships" [9]. However, in their study, this aspect was not included in their final operationalization of SCS.

From our overview, we can conclude that there is a broad range of subjective criteria, or SCS aspects that reflect how one can evaluate their career success $[9,16]$ and that these criteria are being adopted in empirical studies (i.e., [29]). However, much less is known about whether these subjective career success perceptions change over time, how these changes could happen, and what mechanisms may play a role. One of these mechanisms that may be of importance in understanding the dynamic nature of SCS over the course of a career can be drawn from life-span theories and, more specifically, the motivation theory of life-span development, which we will explore in the next section.

\section{Self-Regulation Process as Context for Changing SCS Perceptions}

Shifts in SCS perceptions are potentially symptomatic of achieving and maintaining, which vocational theorists (e.g., [2,14]) argue are an important congruence between personal preferences and abilities and the career environment [9]. In the following section, we argue how the motivational theory of life-span development (e.g., [13]) can extend SCS from a 'static' outcome to a dynamic career outcome that evolves over the course of a career.

When considering life-span development, Heckhausen and colleagues [13] argue that long-term goal striving is vital for a sense of personal agency. They propose that individuals strive for the maximization of primary control goals (e.g., nutrition, shelter, reproduction, and offspring welfare) and that over the course of the career the capacity to achieve these goals first increases, then peaks, and, ultimately, declines with old age [30]. In order to compensate for the decreasing capacity to achieve primary control goals, individuals increasingly engage in secondary control striving over the course of the career, which involves volitional self-regulation to enhance motivational commitment to a chosen goal [13].

Motivational self-regulation in the context of a career can involve goal engagement behaviors (i.e., making strategic career development choices that benefit skill development) and goal disengagement behaviors (i.e., reflecting on past career experiences, considering personal work motives, devaluing goals that are unattainable, and exploring new meanings of work) [31]. Goal selection and prioritization between goal domains (e.g., career, family, 
and health) involves a top-down regulation of goal selection and motivational engagement and disengagement that is reflective of a time perspective and consider opportunities and restraints for achieving primary control in each relevant domain [30].

When considering career success, it can be argued that career goal striving is strongly related to SCS perceptions and potential shifts in career goal striving are likely to be related to shifts in SCS perceptions. For example, when career goals no longer motivate (e.g., financial security and recognition), the formulation of new career goals to improve the current situation can be stimulated as a way of motivational self-regulation [30]. Seeking primary control can lead to career goal shifts as outcomes of motivational self-regulation. Through this adaptive process, career success perceptions can function as a monitor for career outcomes, which provides input for motivational self-regulation that, in turn, informs the process of career goal selection to optimize one's primary control striving. In the continuous process of goal selection and prioritization [32], as workers age, opportunities to pursue certain goals emerge, increase, peak, and decline due to three systematic influences: biological changes related to physical aging, social structural influences, and normative conceptions about life's course [32-34]. Drawing from the motivational theory of life-span development, we argue that for career success perceptions, potential shifts and changes can be expected across the life span of a career. In the following section, we elaborate on the study design we utilized to investigate this dynamic nature of SCS.

\section{Methods}

Given our aim to explore individual reflections on the temporal progression of the importance of SCS aspects, we adopted a qualitative research design using 63 structured in-depth interviews [35]. Through dialogical photo-elicitation [36,37], respondents were primed to reflect on their career history. The interviews were conducted by the first author and four research assistants. The research assistants were trained, coached, and supervised throughout the data collection process by the first author to secure interview quality and consistency. Through coding of the interview transcripts, movements in the importance of SCS aspects were explored and interpreted.

\subsection{Study Sample}

In the study, 63 respondents shared their career histories. Of the respondents, 53\% were female. The average age was 36 years $(s d=15.30 ; \min =22, \max =75)$, with a skew toward younger respondents (ages $22-30=56 \%$, ages $31-50=24 \%$, ages $51-75$ $=20 \%$ ). There is an ongoing discussion on the development of criteria for age cutoffs between career stages [38,39]. In order to select our age cut-offs, we followed past research separating the career trial, stabilization, and maintenance stages, placing respondents in the early career (ages < 31), mid-career (ages 31 through 50), and late-career (ages $>50$ ) stages $[38,39]$. Our early-to-mid cutoff follows prior literature at age 30 , our mid-to-late career cutoff is at age 50 instead of age 45 , as suggested by prior literature, which we did to balance the number of respondents between career phases in our sample [39]. The sample is represented by different career levels and different sectors, centered around college educated workers, all employed in the Netherlands. See Table 1 for a detailed overview.

\subsection{Sampling Strategy}

In our sampling strategy, we sought to obtain a life-span perspective on the development of SCS across all three career phases: early, middle, and late. Interviewing only late career respondents to retrospectively reflect on all three career phases would potentially create errors in the findings because of a recall bias [40]. Therefore, we chose to interview respondents across all three career phases. We approached early-career respondents through the direct social networks of the research assistants. For the mid-career and late-career respondents, the respondents were approached from the lead researcher's business school alumni network and in the research assistants' social networks. The respondents were recruited by phone and e-mail. The respondents received no incentives or compensation 
for taking part in the study. The researchers showed goodwill in participating in the study by explaining the objectives of the study to the participants. A total of 69 interviews were conducted for this study, and a final 63 were used for analysis. Six cases were left out of the dataset, because (1) the audio recordings were lost or inaudible, or (2) because the researcher was not able to complete the interview. All the interviews were conducted between May-July 2019.

Table 1. Sample characteristics.

\begin{tabular}{|c|c|c|c|c|c|}
\hline ID & Pseudonym & Sector & Gender & $\begin{array}{c}\text { Age at Interview } \\
\text { (Years) }\end{array}$ & Education \\
\hline 1 & Saskia & Recruiting & Female & 34 & Bachelor's degree \\
\hline 2 & Robert & FMCG & Male & 75 & Bachelor's degree \\
\hline 3 & Hans & $\begin{array}{c}\text { Professional } \\
\text { services }\end{array}$ & Male & 62 & Master's degree \\
\hline 4 & Sander & IT & Male & 33 & Master's degree \\
\hline 5 & Margot & IT & Female & 38 & Master's degree \\
\hline 6 & Sara & IT & Female & 32 & Master's degree \\
\hline 7 & Sarah & PR & Female & 52 & Bachelor's degree \\
\hline 8 & Chantal & Finance & Female & 31 & Master's degree \\
\hline 9 & Karel & $\begin{array}{l}\text { Professional } \\
\text { services }\end{array}$ & Male & 61 & High school degree \\
\hline 10 & Anton & Engineering & Male & 32 & Master's degree \\
\hline 11 & Egbert & IT & Male & 30 & Master's degree \\
\hline 12 & Mariam & Tourism & Female & 39 & Bachelor's degree \\
\hline 13 & Daniela & IT & Female & 24 & Master's degree \\
\hline 14 & Laura & $\begin{array}{l}\text { Professional } \\
\text { services }\end{array}$ & Female & 28 & Master's degree \\
\hline 15 & Sarah & Hospitality & Female & 24 & Bachelor's degree \\
\hline 16 & Omar & Hospitality & Male & 25 & Bachelor's degree \\
\hline 17 & Frank & Hospitality & Male & 25 & Master's degree \\
\hline 18 & Annemarie & $\begin{array}{l}\text { Professional } \\
\text { services }\end{array}$ & Female & 26 & Master's degree \\
\hline 19 & Rutger & Engineering & Male & 28 & Master's degree \\
\hline 20 & Rick & Automotive & Male & 61 & High school degree \\
\hline 21 & Leonie & Trade union & Female & 52 & Bachelor's degree \\
\hline 22 & Jos & Finance & Male & 25 & Master's degree \\
\hline 23 & Stephanie & Hospitality & Female & 27 & Master's degree \\
\hline 24 & Marieke & Entertainment & Female & 25 & Master's degree \\
\hline 25 & Ellen & Hospitality & Female & 27 & Master's degree \\
\hline 26 & Katrien & $\begin{array}{l}\text { Professional } \\
\text { services }\end{array}$ & Female & 26 & Master's degree \\
\hline 27 & José & Consultancy & Male & 25 & Master's degree \\
\hline 28 & Dita & Construction & Female & 26 & Master's degree \\
\hline 29 & Jan & IT & Male & 25 & Master's degree \\
\hline 30 & Chloe & $\begin{array}{l}\text { Professional } \\
\text { services }\end{array}$ & Female & 27 & Master's degree \\
\hline 31 & Yvonne & Education & Female & 28 & Master's degree \\
\hline 32 & Danielle & IT & Female & 25 & Master's degree \\
\hline 33 & Meta & FMCG & Female & 28 & Master's degree \\
\hline 34 & Gerard & IT & Male & 29 & Bachelor's degree \\
\hline 35 & Heleen & IT & Female & 25 & Bachelor's degree \\
\hline 36 & Henk & IT & Male & 26 & Master's degree \\
\hline 37 & Monique & IT & Female & 29 & Bachelor's degree \\
\hline 38 & Steven & IT & Male & 27 & Bachelor's degree \\
\hline 39 & Mandy & Education & Female & 27 & Bachelor's degree \\
\hline 40 & Roberto & Finance & Male & 26 & Master's degree \\
\hline 41 & Dennis & FMCG & Male & 29 & Bachelor's degree \\
\hline 42 & Ruben & IT & Male & 34 & Bachelor's degree \\
\hline
\end{tabular}


Table 1. Cont.

\begin{tabular}{|c|c|c|c|c|c|}
\hline ID & Pseudonym & Sector & Gender & $\begin{array}{c}\text { Age at Interview } \\
\text { (Years) }\end{array}$ & Education \\
\hline 43 & Simone & HR & Female & 37 & Master's degree \\
\hline 44 & Louis & IT & Male & 39 & Bachelor's degree \\
\hline 45 & Benedita & IT & Female & 27 & Bachelor's degree \\
\hline 46 & Roderik & FMCG & Male & 22 & Bachelor's degree \\
\hline 47 & Frank & FMCG & Male & 28 & Master's degree \\
\hline 48 & Erik & IT & Male & 27 & Bachelor's degree \\
\hline 49 & Maria & FMCG & Female & 22 & Master's degree \\
\hline 50 & Henk & IT & Male & 29 & Bachelor's degree \\
\hline 51 & Ton & Government & Male & 63 & Master's degree \\
\hline 52 & Robin & Government & Female & 56 & Bachelor's degree \\
\hline 53 & Anton & Manufacturing & Male & 43 & Bachelor's degree \\
\hline 54 & Diana & Manufacturing & Female & 46 & Master's degree \\
\hline 55 & Jos & PR & Male & 56 & Bachelor's degree \\
\hline 56 & Catarina & Healthcare & Female & 44 & Master's degree \\
\hline 57 & Michael & Capital Goods & Male & 62 & Master's degree \\
\hline 58 & Thomas & Aviation & Male & 72 & Master's degree \\
\hline 59 & Marta & Government & Female & 51 & Master's degree \\
\hline 60 & Linde & $\begin{array}{l}\text { Professional } \\
\text { services }\end{array}$ & Female & 67 & Bachelor's degree \\
\hline 61 & Daniela & Healthcare & Female & 49 & Bachelor's degree \\
\hline 62 & Gaida & Manufacturing & Female & 50 & Bachelor's degree \\
\hline 63 & Wim & Fashion & Male & 24 & Master's degree \\
\hline
\end{tabular}

Abbreviations: PR: Public Relations, IT: Information Technology, FMCG: Fast Moving Consumer Goods.

\subsection{Data Collection}

The 63 interviews that were included for further analysis were conducted by the first author and four research assistants. The interviews were conducted in either Dutch or English and lasted on average $50 \mathrm{~min}$ ( $\mathrm{min} 33 \mathrm{~min}$, max $88 \mathrm{~min}$ ). All the interviews were performed in a one-on-one setting with the respondent and one of the researchers. The audio was recorded using the researcher's mobile phone microphone and audio recording software. Throughout the data collection process, no changes were made to the interview protocol to maintain consistency across the interviews and between interviewers. The recorded audio was transcribed verbatim.

During the interviews, the following steps were executed in order: (1) the research context and the topic of SCS aspects were explained to the respondents, (2) the respondents scored themselves on each SCS aspect, (3) a graphical career timeline was made by the respondents, from which the respondents chose five pivotal moments or periods, and (4) the interview focused on the importance of these events on the temporal development of SCS across the respondent's career.

In order to stimulate the respondents' career history salience, a graphical career timeline was created and double checked by the respondents with the help of the researchers (see Figure 1 for an example). This approach is based on the life history method, which is characterized by a high degree of autonomy for the respondent and a chronological treatment of events [41,42]. The respondents were asked to mark all pivotal moments and key periods that they experienced throughout their career by arrows and dots on their career timeline, which functioned as interview anchors. From this timeline, a selection of the most critical moments was made in collaboration with the respondent to provide reference points to talk about the respondents' career experiences. In the interviews, by means of open questions, the respondents were asked to tell the narrative of their career and reflect on the key moments highlighted by the respondent. The respondents were asked to reflect on their SCS perceptions, using the career timeline as an anchor to place the SCS perceptions in each career phase. In reflecting on SCS perceptions, the respondents were able to draw from the SCS aspects scored in step 2 of the interview process. The nu- 
meric scores for the SCS aspects were used to aid respondents with vocabulary to express their SCS perceptions and to provide an overview of how SCS aspect preferences were at the time of the interview. By measuring SCS in the interview, the respondent could then consequently go back to their career timeline and consider how their SCS perceptions may have developed over the course of their career (see Appendix A for an overview of all the open questions used in the interview protocol). The researchers used the open questions in conjunction with the graphical career timeline that the respondents created together with the researcher to create an SCS perception timeline. See Figure 1 for a detailed overview.

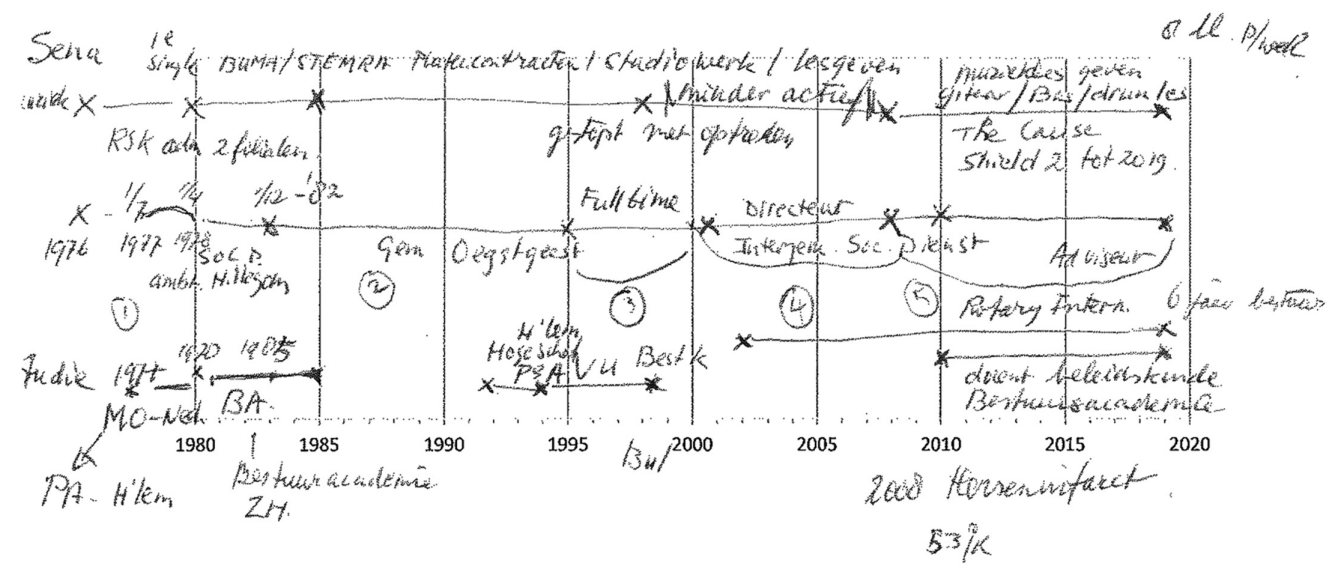

Figure 1. An example of a timeline created by a respondent used to create saliency for the respondent's career history. The numbers indicate the critical periods discussed in the interview. The crosses indicate pivotal moments, and the lines indicate pivotal periods from the respondent's career history.

\subsection{Analysis}

To ensure methodological rigor, we drew on the existing literature on qualitative methods to inform our analysis [43-48]. Specifically, we view the study of the temporal development of SCS as a complex process, where multiple paths are possible in the data. A case-based approach allowed us to uncover and interpret our findings appropriately [43]. To facilitate our coding process, we used Atlas.ti version 8.4.4 [49], a software tool that allows for computer-assisted qualitative data analysis. We started the analysis by opencoding each transcript [50] to obtain an overview of the different perceptions on career success. We then continued the analysis by developing relationships between these codes and fleshing out the different career success perception trajectories that the respondents had experienced during their careers. Through this procedure, we uncovered five shift components in SCS perception by taking a process perspective [51]. In order to arrive at these shift components, we first developed a coding scheme using the first fifteen interviews, which was oriented toward any references (events, activities, and experiences) to change in career success perceptions and priorities over the course of the career, and the period (early, mid, or late) in the career in which this change was experienced [50]. The codes for change in career success perceptions over the course of a career provide the foundation for the integration of the data to develop the change patterns that emerged. By iteratively reviewing the ongoing coding process between the lead author and co-authors, and by going back and forth between our codes and existing work on the operationalization of career success, we sought to mitigate researcher biases in our coding procedure $[9,16]$. The first author developed the initial coding scheme and had iterative discussions with the second author, followed by discussions with the other authors to progressively refine the coding scheme. We coded all the interviews for changes in career success perceptions per career phase. This allowed us to arrive at the shift components of SCS. The coding scheme received minor extensions up to saturation, after which the coding scheme remained the same for the rest of the analysis process. 


\section{Findings}

Before investigating potential patterns of change in SCS we first confirmed whether the previously developed $[9,16]$ eleven aspects of career success were recognized by the respondents. We found all eleven aspects reflected upon within our 63 interviews. Table 2 shows an overview with example quotes, which display how the respondents reflected on each aspect. Behind each respondent number, we display the career phase that the respondent was in at the time of the interview.

Table 2. Quotes per SCS aspect.

\begin{tabular}{|c|c|}
\hline Aspect & Example Quotes \\
\hline 1 Autonomy & $\begin{array}{l}\text { R9 (late-career): "I think you get the most happiness when you're } \\
\text { working for yourself than if you're working for somebody else." } \\
\text { R32 (early career): "I believe that in the modern world it's quite } \\
\text { important to have as much flexibility as you want." }\end{array}$ \\
\hline 2 Personal development & $\begin{array}{l}\text { R53 (mid-career): "Now I'm motivated by lifelong learning. I can't } \\
\text { do anything else. [ . . . I It's just important. It will become more } \\
\text { important. Right now, I am still able to learn but soon I'll be } 50 \\
\text { years old and then you still need to matter. [ . . . I If you get fired } \\
\text { you won't be hired again so you need to stay current". } \\
\text { R36 (early-career): '[ ... I to feel motivated about your work, your } \\
\text { job, and to feel that you are learning something." }\end{array}$ \\
\hline 3 Influence & $\begin{array}{l}\text { R40 (early-career): "You start looking into other things, such as, I } \\
\text { would say, the impact that you [have] on your colleagues and staff } \\
\text { and the team you're working with, also externally on society, like } \\
\text { what you do influence and effect on the surroundings and the people } \\
\text { around you." }\end{array}$ \\
\hline 4 Service to others & $\begin{array}{l}\text { R20 (late-career): "To give others the opportunity to evolve, to grow, } \\
\text { and have their moments of success." } \\
\text { R50 (early-career): "Now it has changed a lot, for example, how to } \\
\text { be able to share this knowledge and to find someone who can use the } \\
\text { knowledge you have, so transferring this information to other people } \\
\text { is considered a success for me." }\end{array}$ \\
\hline 5 Work-life balance & $\begin{array}{l}\text { R45 (early-career): "Career success is working in something that I } \\
\text { really like, I enjoy doing it every day, having work life balance, so I } \\
\text { can go home and really enjoy my life. If I'm working in a very good } \\
\text { company with a big name, but have no work life balance, it's } \\
\text { meaningless to me." }\end{array}$ \\
\hline 6 Quality work & $\begin{array}{l}\text { R58 (late-career): "During my time at [Company], I've been asked } \\
\text { many times to speak about my work. At [Dutch University], I gave } \\
\text { many lectures about alliances for international master students that } \\
\text { also had alliances in their course contents." }\end{array}$ \\
\hline 7 Recognition & $\begin{array}{l}\text { R40 (early-career): "[A] very important part is getting recognized } \\
\text { and, you know, feeling appreciated for what you do." }\end{array}$ \\
\hline 8 Career satisfaction & $\begin{array}{l}\text { R27 (early-career): "I generally think that the times that I had more } \\
\text { success in my life were the times that I was fully enjoying what I } \\
\text { was doing." } \\
\text { R63 (early-career): "So for me, like, the most important thing is to } \\
\text { do something that I really like to do, and that I wake up, and I want } \\
\text { to do it, because it's of my personal interest." }\end{array}$ \\
\hline 9 Financial security & $\begin{array}{l}\text { R3 (late-career): "First of all, it's financial stability. I mean, I need } \\
\text { to earn a living." }\end{array}$ \\
\hline
\end{tabular}


Table 2. Cont.

\begin{tabular}{cl}
\hline \multicolumn{1}{c}{ Aspect } & Example Quotes \\
\hline R36 (early-career): "First, I wanted just money. I just wanted to \\
make as much money as possible." \\
R37 (early-career): "I said that [with] a good career, that you should \\
have a big salary, so I always choose the company with the biggest \\
salary." \\
R18 (early-career): "It's important the feeling that I have and also \\
the feedback from the other persons that work with me. So, in that \\
sense, if I have a good feedback, and it's going in the same way as \\
what I feel, then I'm sure that I'm achieving those goals."
\end{tabular}

As a second step in our analysis, we investigated potential patterns of change in SCS. We asked the respondents about their primary goal domain in terms of SCS. In our analysis, we found five distinct patterns reported by the respondents, which describe movements between aspects of SCS. These are (1) quitting striving for financial success and recognition; (2) increased focus on personal development across the career; (3) stronger emphasis on work-life balance across the career; (4) a shift toward being of service to others; and (5) no change in subjective career success perceptions across the career. Figure 2 depicts these patterns. In the figure, we group shifts in SCS by the early, mid, and late career phases. This categorization in time is visible as the space between the columns of the SCS aspects. Within this space, using arrows, the discovered patterns are graphically depicted. Shifts between the same SCS aspects in the same direction have the same colors for each time period. It is important to note that only 7 out of the 11 SCS aspects are reflected in Figure 2. The respondents did report almost all of the 11 aspects in the interviews, but the respondents only reported the depicted 7 aspects in the context of time. It is for these 7 aspects that clear patterns of continuity and shifts were confirmed in our analysis and are therefore included in our visualization.
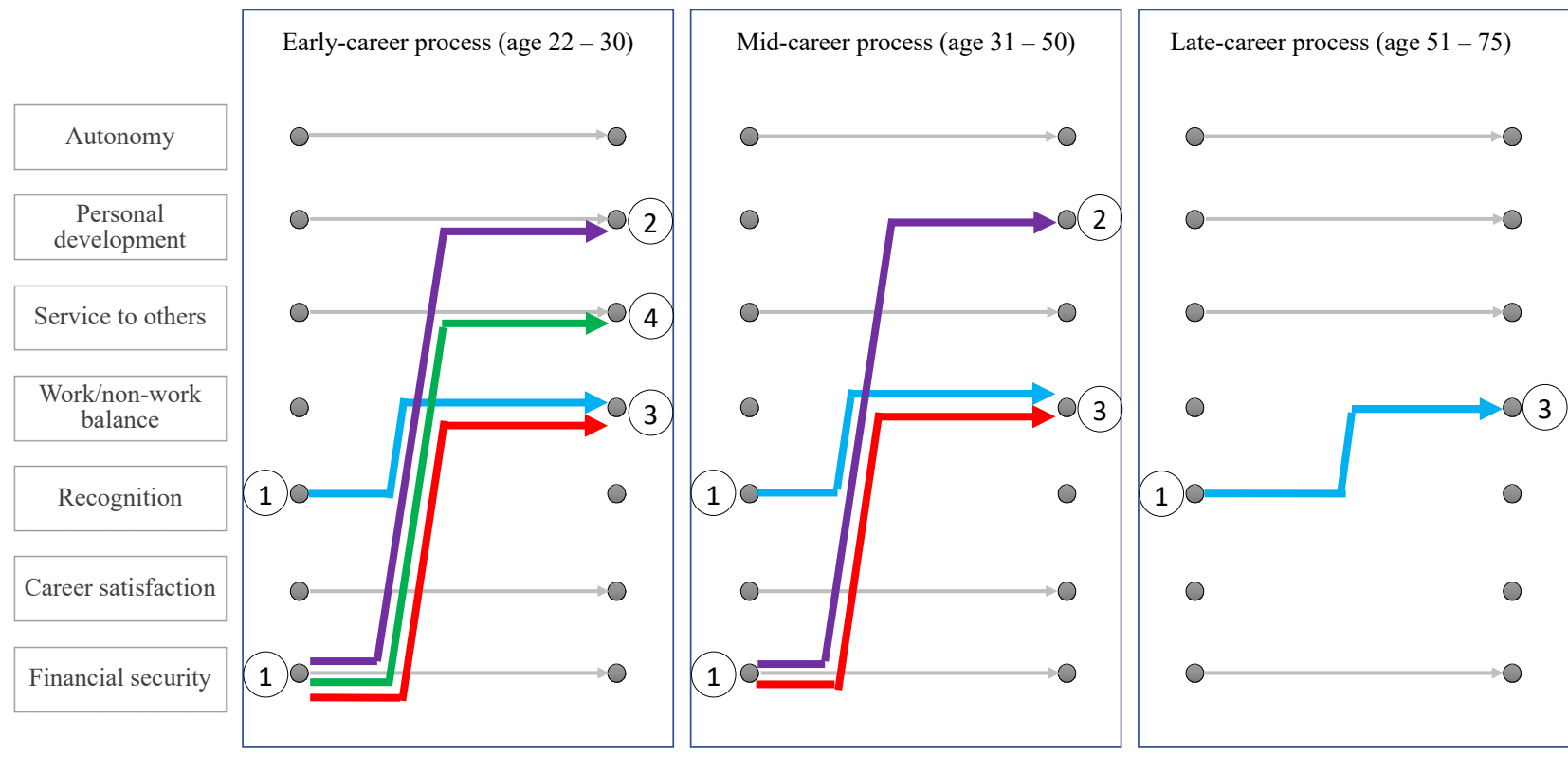

Figure 2. Shift components (numbers) for each change pattern (colored lines) in SCS perception. Shift component 1, quitting striving for financial success and recognition; shift component 2, increased focus on personal development across the career; shift component 3, stronger emphasis on work-life balance across the career; shift component 4, a shift toward being of service to others; and component 5, persistent (no change) importance in subjective career success aspects across the career, which is represented as grey lines in each career process stage. 
Figure 2 provides a general overview of all the patterns of change in SCS perceptions that our respondents reported. When observing all changes in the figure, important observations can be made. First, the respondents report more change in SCS perceptions in the early career and mid-career than in the late career. Second, when SCS perceptions shift, it is commonly those respondents that start from a focus on recognition and financial security. Third, when SCS perceptions shift, personal development, work-life balance, and service to others are common endpoints. Because of these commonalities, we argue that change in SCS perceptions is best described in terms of the shift components, which are (1) quitting striving for financial success and recognition; (2) increased focus on personal development across the career; (3) stronger emphasis on work-life balance across the career; (4) a shift toward being of service to others; and (5) no change in subjective career success components across their career. In the following section, we highlight each shift component and elaborate on the narratives that allowed them to surface.

\subsection{Shift Component 1: Quitting Striving for Financial Security and Recognition}

The importance of financial security and recognition are common career success themes in our sample, as the majority of respondents reflect upon these SCS aspects as important during their early- and mid-career. When we look at financial security specifically, the respondents talk about working on financial stability and becoming independent and self-reliant as key reasons as to why financial security is a central aspect of their career success. In addition, the respondents in our study share that their early career-design goals were strongly influenced by the need to create financial security in order to have a successful career.

R63 (early-career): "Yes, in the beginning, we have to imagine that we should get a job that offers like, you know, money for us, no matter how difficult it is."

R53 (mid-career): "Being able to make enough money was very important in the beginning."

A parallel career success perspective on financial success is about recognition and financial success. The difference with financial security is the underlying rationale behind the drive to achieve financial goals. When talking to respondents about financial success as an aspect of the total career success, the respondents explained that they wanted to make money just for sake of being able to make any money at all, where financial success strivers view their career as successful when they have made as much money as they possibly can and are recognized for it. In these examples, there is no question as to whether the respondent views themselves as able to make any money but relates their career success specifically to the maximum income that they are able to achieve.

R36 (early-career): "Oh definitely yeah, it has changed. First, I wanted just money, I just wanted to make as much money as possible."

The focus of respondents on financial security and recognition is, as we have displayed in Figure 2, a commonly mentioned starting point for career success. However, the respondents report that their perceptions of SCS start to shift away from these aspects to personal development, work-life balance, and service to others. This shift is reported by the respondents to occur in all three career phases, yet they are most common in the early-career and mid-career stages. Respondent 53 illustrates this transition well by describing how, over the course of the career, material concerns decline:

R53 (mid-career): "At some point, you realize that enough is enough, that it's nice to have. It sounds very cocky, but I don't mean anything by it. You have a certain need, which is enormous in the beginning. You want to buy a house, buy a car, and you want to go on holiday while your pay is still low. At some point, your wages go up. The weird thing is that the costs go down. You have the car, you have the house, and the rent goes down. At some point, the lines cross each other, and from that point on, nothing [...] matters anymore. I don't care about it anymore. Maybe a little, but it's not a motivator anymore." 
The word 'motivator' stands out in this quote. The respondent describes how motivation for monetary rewards declines over the course of the career. It is this change in perceived motivation that hints at a mechanism that describes how change in SCS is initiated. Besides financial security, the respondents referring to their development in SCS refer to their initial focus of career success to revolve around gaining social recognition and validation. The respondents describe how they built their expectations of career success around the position of a specific place in a social hierarchy. The importance of others expressing their recognition toward them is stressed here.

R51 (late-career): [Referring to a personal mantra] "I have to perform, and everyone has to tell me I am doing an excellent job."

This general focus on recognition is commonly talked about by respondents in the earlycareer phase. It interlinks with the process of building a reputation in society; to making the right choices and setting the appropriate goals to find and secure a solid role in society. Through recognition, this role can be further solidified and provide a basis for flourishing in the mid-career and late-career stages. However, at this point, the respondents describe how their SCS perceptions change.

R43 (mid-career): "When I was your age, I could only think of one or two years ahead of me that I want to do this, or I want to achieve this title."

R14 (early-career): "In the beginning, you don't know anything about work. You are just having the first experience. And afterwards, you start to meet other people, [ ...] and you listen to your colleagues and their experiences. So, I believe that my goals also changed [ ... ]. Having work-life balance is a main goal. In the end, when you have this personal life, and when you are happy, then you feel that you are better."

The respondents explain that in their pursuit of recognition, they purposefully put private life aside as an important aspect of career success. A central component of departing from material concerns toward other SCS aspects concerns a learning experience that the respondents report when they are achieving their originally intended career success goals. Respondent 62 exemplifies this point:

R62 (mid-career): 'I believed for way too long that if I work hard enough, I will become happy. Back then, I had that good job and lots of money. I remember what I thought back then: hmm, this isn't it really ... ha ha."

In sum, we found that financial security and recognition are common career success goals that are volatile, i.e., they can lead to a shift to other SCS aspects. The respondents engage in career building, looking to build a life of their own and relate themselves to their social environment. From here, the respondents report key events and experiences that can motivate them towards goals other than financial security and recognition.

\subsection{Shift Component 2: Increased Focus on Personal Development across the Career}

Growth and learning are commonly mentioned as important aspects of SCS by the respondents, especially in the mid- and late-career stages. When talking to the respondents about personal development in the context of career success, the respondents refer to the importance of experiencing new situations and contexts that stimulate learning. The respondents underline the importance of going through new experiences to gain a sense of progression in working toward goals linked to career success perceptions. When asking about their motives for pursuing personal development as a key career success aspect, the respondents report the importance of experiencing a learning process, and they mention the importance of the maintenance and improvement of employability, to remain attractive and flexible in their job market, like this mid-career respondent:

R53 (mid-career): "Now I'm motivated by lifelong learning. I can't do anything else. I ... I It's just important. It will become more important. Right now, I am still able to learn, but soon I'll be 50 years old, and then you still need to matter. [ ... I If you get fired, you won't be hired again, so you need to stay current". 
Personal development can also contribute to the need for personal challenge. By testing oneself in new contexts and learning environments, the respondents share a sense of fulfillment in the process of challenging themselves and looking to gain new skills.

R43 (mid-career): "At the beginning, it was like achieving new technologies, learning new things, making good money. This has been going on for a long time. Learning new things made you feel the discomfort zone staying with you for ten years. You're always learning new things.

R36 (early-career): "I realized that, regarding work, it's more important to feel that you are learning something."

When we look at personal development as an SCS aspect over the course of the career, the respondents report either that personal development was always a central aspect of their career success, or the respondents talk about how they shifted from financial security toward personal development in their SCS perception in either the early- or the mid-career. This change is mentioned by respondents from all three career phases. The motives for change in SCS perceptions vary greatly between respondents, but there are some commonalities. Most importantly, financial security as a career success goal does not motivate the respondents anymore; it does not appear to the respondents as an attractive career goal to pursue. When considering alternatives, personal development surfaces as a new goal to pursue for a group of the respondents, which is reported to occur in either the early- or the mid-career.

\subsection{Shift Component 3: Stronger Emphasis on Work-Life Balance across the Career}

When talking about subjective evaluations of career success, work-life balance is an aspect that respondents from all three career phases consider in their process of selfevaluation. The respondents report about learning experiences, where the motivations for financial security and financial success turn to motivations toward work-life balance.

R53 (mid-career): "First, it was getting everything there is to get, and now, I don't have it at all. Career success is about doing what you feel comfortable doing, not achieving the maximum."

Aging can play a role in changing SCS perceptions. Over the course of a career, work-life balance can become a more salient SCS aspect, as described by respondent 11:

R11 (early-career): "I think over time the thing that changes the most is the work-life balance thing, where in the beginning you're like I can work all day. Like when I had my own business, I worked $16 \mathrm{~h}$ days, right; I really didn't care a lot. But now, I think when you become older, you care more about actually the time you spend outside of work. So, that was probably one that changes a lot over time, I would say."

This quote shows that working on a personal project can be such an all-encompassing engagement that no time is spared for pursuing the SCS related to these endeavors. Over time, these goals can change, and other, non-work goals can become more salient. This is also illustrated by a general sense of seeking balance in the career between work and non-work commitments.

R45 (early-career): "Career success is working on something that I really like, I enjoy doing it every day, having work-life balance, so I can go home and I really enjoy my life. If I'm working in a very good company with a big name, but have no work-life balance, it's meaningless to me."

Aging can include a rising desire to start a family. This desire can greatly influence what SCS aspects are important to the respondents. More specifically, the aspect of work-life balance becomes more important, especially during the mid-career stage. Parenthood can have a strong influence on SCS perceptions and the overall perceptions of what really matters to the respondents, as is best described by respondent 43 : 
R43 (mid-career): "Now, career success is a part of a big picture, so life is the big umbrella, and then career and career success is only part of it. When you are younger, you don't think of the whole picture. You think of the title, the money, the car, but now, my family comes first."

This quote describes exactly how SCS perceptions can change from a focus on financial security and recognition toward work-life balance. From the interviews, we find that an important part of SCS concerns the interaction between work-life and private-life. Individuals look to balance these two and evaluate their career success by their ability to find and maintain this balance.

R35 (early-career): "Now, I think it's like being successful in your career is like having a nice, balanced life."

\subsection{Shift Component 4: Shift toward Being of Service to Others}

Service to others as an SCS aspect is unique to the other aspects, as the goal-setting related to this aspect is primarily focused on the concerns of others, instead of concerns relating to personal matters.

R52 (late-career): "I am very happy I can contribute to something, that I can be there for young people - people that need my help. It moved a lot from wanting to be told I am great toward contributing to others. I like this development."

Respondent 52 exemplifies how SCS perceptions can shift between recognition and service to others, showing how taking care of people that require help can become an important SCS aspect.

R57 (late-career): "In the beginning, I thought I really wanted to work for a big company, like [ ... ], and build a career there. Currently, it is completely different. I am all about entrepreneurship, which is much more fun. That is why I am so happy that today's youth don't feel attracted to big corporates and want to start their own business. They want to add something of value. I want to support society."

As the two quotes above describe, the desire to be of service of others can be an acquired aspect of SCS. While some respondents report a focus of service to others as a key SCS aspect, the respondents also report a shift toward service to others, rather than starting out with this SCS aspect. Through behavioral examples (e.g., role models), seeing the opportunity and the results of helping others and feeling successful because of the success of others by helping them thrive are shown to be important SCS aspects. This aspect of SCS is characterized by a high level of selflessness, where aligning the goals of others to your own is important for being able to facilitate others in their process of development across the career. The respondents share that providing a coaching and supporting role comes naturally in the late career, as encounters with others that are in an earlier career stage become more frequent over the course of the career.

\subsection{No Shift in SCS Perception}

A section of the respondents from all three career phases reported no change in their SCS perception over time, a persistent career success perspective over the career up to the point of the interview. An argument for this pattern could be that the respondents were still very early in their career and did not spend enough time living to gain experiences that might influence their SCS perception in a later stage of their career.

R18 (early-career): "No, not really. All these things that we have been talking about are the things that I have in my mind since I started working. Well, it's not so long, so it's still the same."

R13 (early-career): "Not really ... The thing is that I don't have a career for that long ... But I think the core has remained the same. My definition has remained the same."

However, being only in the early career phase is not the only argument for a lack of change in SCS perceptions, as mid- and late-career respondents also report SCS perception stability. 
In addition, the respondents report various different arguments for the stability of their SCS perceptions across their career. One of these arguments concerns respondents connecting their core values to their SCS perceptions.

R10 (mid-career): "I would say it did not change much over time, because I always wanted to give my best. I always wanted to contribute in a way to the greater good by way of sustainability"

R8 (mid-career): "I can't say that they change over time, because they're also like a part of who I am."

R34 (early-career): "First of all I need to do what I like, and I am doing what I like. I need to be unique among my team members, and also I am unique among my team members. I need to gain more money, and I'm gaining more money, so I can say no. It didn't change until now."

R39 (early-career): "Mm hmm, I think no, I didn't change my definition, because the definition of career success for me has always been to reach high positions."

Another argument for the SCS aspect of stability can be the formation of career goals early in life that remain important throughout the career, as is the case with respondent 46 :

R47 (early-career): "I think the definition has not changed for me. Career success is important in my personal case and not applicable to anyone, but in my personal case, I would consider myself as having a successful career if I managed to have my own business running and functioning and doing well. In this case, the chocolate brand that I want to start in a few years - that's my definition of success, and I've always had it, so I don't know, for somebody else, maybe it would be a CEO of a company, or whatever industry. But in my case, I always had this vision since I was a teenager, so no, I would say that it has not changed."

The respondents can find their key focus in career success very early in the career and stick with it throughout the career. For example, young entrepreneurs who are self-employed and are born into a family that fosters an entrepreneurial attitude and mindset toward the career may foster autonomy across their entire career.

\subsection{Overview of Changes in SCS Perceptions}

In the previous sections, we described how the respondents' evaluations of their SCS aspects are reflected in each of the five shift components. Through quotes, we have outlined the key facets of each component in order to provide a good overview of all aspects that came forth in our investigation of the dynamic aspects of SCS. In Table 3, we bring the five shift components together and outline key experiences that relate to each component.

In order to integrate the five shift components, we have to connect our findings to a theoretical framework that provides key assumptions and propositions that can help explain our uncovered SCS aspects. In the discussion section, we highlight how motivation, using the motivational theory of lifespan development [13] and time perspective using SST [17], provide the theoretical groundwork for the findings in our study. 
Table 3. Overview of the shift components and a description of related experiences.

\begin{tabular}{|c|c|c|}
\hline Nr. & Shift Component & Experiences \\
\hline 1 & $\begin{array}{l}\text { Quitting striving for } \\
\text { financial security and } \\
\text { recognition }\end{array}$ & $\begin{array}{l}\text { Goals pertaining to financial security and } \\
\text { recognition do not motivate anymore. This shift } \\
\text { away from financial security and recognition is } \\
\text { reported to occur in the early- and mid-career. }\end{array}$ \\
\hline 2 & $\begin{array}{c}\text { Increased focus on personal } \\
\text { development }\end{array}$ & $\begin{array}{l}\text { Workers seeking personal development want to } \\
\text { expand their horizon, because goals concerning } \\
\text { personal development have become more attractive. }\end{array}$ \\
\hline 3 & $\begin{array}{l}\text { Stronger emphasis on } \\
\text { work-life balance }\end{array}$ & $\begin{array}{l}\text { Workers seeking more work-life balance seem to } \\
\text { choose this option to minimize investments in work } \\
\text { in general, because non-work goals have become } \\
\text { more attractive. }\end{array}$ \\
\hline 4 & $\begin{array}{c}\text { A shift toward service to } \\
\text { others }\end{array}$ & $\begin{array}{l}\text { Workers going for service to others also have high } \\
\text { career outcomes. They have gained an expanded } \\
\text { definition of self, as a process of maturation } \\
\text { (generativity as a sign of maturation) and have } \\
\text { experienced joy and inspiration in working with } \\
\text { others in a communal sense. }\end{array}$ \\
\hline 5 & No shift in success criteria & $\begin{array}{l}\text { Workers experience consistent SCS perceptions } \\
\text { across career phases. }\end{array}$ \\
\hline
\end{tabular}

\section{Discussion}

Through a qualitative enquiry, utilizing dialogical photo-elicitation, this paper examined how the respondents' SCS evaluation changes over the course of their career. Drawing on 63 interviews with respondents across all career stages, our analysis has brought forth five distinct shift-components that describe how SCS can develop over the course of a career. These components describe key changes that occur within SCS perceptions over the course of a career as (1) quitting striving for financial success and recognition success criteria; (2) increased focus on personal development across the career; (3) stronger emphasis on work-life balance across the career; (4) a shift toward being of service to others; and (5) no shift in subjective success criteria across the career.

\subsection{Developing Personality as a Mechanism for SCS Change}

Component four of the changes in SCS across the career describes the increase in service to others as a central SCS aspect. This coincides with emergent generativitymotives [52] over the course of the career. One explanation for this SCS dynamic can be found in personality psychology. Recent evidence shows an upward trend of honesty and humility between the ages of 18 and 60 [53]. There is no direct evidence that personality, and honesty and humility specifically, relates to subjective evaluation of the career. However, it is likely that honesty and humility, and specifically its subscales, modesty and greed avoidance, could relate to the development of generativity motives [54]. In this conceived process, a person expands their evaluation of career success toward the care for others, because one's personality develops toward a more equal valuation of others in comparison to the self. The gradual shift of concern for self toward concern for others may drive an increased motivation toward helping others over the course of the career.

\subsection{Changing Motivation and Time Perspective as Mechanisms for SCS Change}

A primary conclusion from our findings is that financial security and recognition are common starting points, which decline in importance as SCS perceptions over the course of the career. Through key events and experiences, the respondents report that their motivation for the achievement of financial security and recognition decline. These events include the attainment of the basic necessities for living, the attainment of recognition, and the evaluation of career outcomes. In their meta-analysis, Kooij and colleagues [18] investigated how work-related motives develop over the life-span. Their findings on 
motivation show that security and extrinsic motives decrease with age. This aligns with the decline of subjective evaluation of the career in terms of financial security. In addition, intrinsic motives tended to become more important with aging [18]. This finding coalesces with our shift component toward service to others, which involves generativity as an emergent motive (Slater, 2003), i.e., facilitating younger generations in attaining their career success. Service to others is a strong 'do-good' and value-based aspect, which relates to engaging in work that is personally and socially valued [55].

SCS encompasses all subjective evaluations of the career [6,15]. In this process of evaluation, goal-setting plays an important role, because goals define both the yardstick and the expectations, which are used as reference points for evaluating one's career. When it comes to goal setting, the socioemotional selectivity theory (SST) suggests that in situations where goals compete with one another, the time perspective acts as a principal mechanism for goal selection [24,56]. When time is perceived as open-ended (e.g., in the early- and mid-career), stretching and audacious goals can be pursued. As the resource of time becomes scarcer, goals tend to orient toward outcomes that help with emotion regulation. SST suggests that this is because fulfillment of the latter pays off directly, as opposed to the pursuit of big goals, where the payoff is at some unknown time in the future. The evaluation of the future time perspective (e.g., temporal appraisal) affects how workers balance the fulfillment of short and long-term needs. The process of aging stimulates the awareness that time is eventually going to run out, which stimulates a focus on the present, instead of the future. This motivates the attainment of goals that are satisfied by feeling states over goals that are achieved over a prolonged period because of the immediacy of the payoff of these goals. This immediacy becomes more valuable in the face of time and is more and more limited. As people age and approach life's end, people care more about the experiences of meaningful social interactions and less about broadening one's horizon. This shift in motivation leads to more investment in close social relationships and an overall appreciation of life [24]. Kanfer and Ackerman [57] suggest that the shift in future time perspective reduces the salience and appeal of extrinsic work-related outcomes, like pay and advancement. Therefore, we argue that the future time perspective contributes to motivational shifts in explaining the decline of financial security and recognition as SCS aspects.

Complementary to SST, career-related goal-setting provides the theoretical link between SCS and the motivational theory of lifespan development [13], as we argue that career goals function as reference points for the subjective evaluation of career success. A central assumption of the motivational theory of lifespan development is that individuals seek out multidomain and long-term capacity for primary control [13]. Whether control strategies are adaptive is related to how realistically attainable the set goals are in a given context and that there are no excessive consequences for control striving in a given domain, compared to other goal domains. For SCS, this means that career-related goal-setting and, consequently, career success self-evaluation is influenced by the ability of workers to adaptively set career goals that are both attainable and not in conflict with other goal domains.

In studying how SCS perceptions change over the course of the career, we found four shift components that describe the choice of, engagement with, and withdrawal of career-goals. The action-phase framework for developmental regulation [32] (Figure 5.1, p. 115) provides a theoretical perspective to explain the shift components that surfaced in our study. The transitioning between primary SCS aspects can be understood and explained by studying the process described by the action-phase framework. For example, the SCS perception shifts toward career goals related to work-life balance, when understood from a life-span developmental context, are related to goal-related opportunities declining with age (e.g., biological clock for child bearing) [30]. This decline of goal-related opportunities through aging can be an important trigger for SCS shifts. For career success theory, this means that as goal-related opportunities change over the course of the career, career success 
perceptions can shift, as different opportunities and the ability of workers to engage primary control of these goals changes along the career timeline.

When workers shift their SCS perceptions, we follow the idea that career success goals have to be abandoned before new career success goals can be pursued. As Heckhausen and colleagues [30] argue, experiencing not being able to achieve a (career) goal demands workers to adjust their motivational response. When career goal choices are incompatible with workers' opportunity structure, workers need to disengage from these career goals and seek out realistic alternatives.

This process involves the experience of an action crisis that adjusts a worker's positively biased beliefs about their goal attainment, which instigates an assessment process for evaluating current goals and potential alternatives [58]. A potential outcome of this process, as Heckhausen and colleagues argue [30], is a withdrawal of commitment toward the original goals, creating opportunity for new choice and engagement, which is helped by the availability of attractive alternative goals [59]. For career success theory, this means that the ability of workers to adaptively choose, engage with, and disengage from career goals is likely to predict variability in SCS perception variability over the course of a career.

A third and final input for SCS from the motivational theory of life-span development resides in the understanding of motivational self-regulation throughout the career. It is suggested that behavioral evolution has preferred mechanisms of motivational self-regulation that do well to maximize primary control striving. For career success, this means that changes in SCS perceptions can be the result of workers self-regulating their motivation toward their career goals by continually developing conceptions of career success that are beneficial and attainable, given the goal opportunities and developmental deadlines [13].

To summarize, we find five SCS shift components that describe how SCS perceptions can change over the course of a career. From a developmental lifespan perspective, these changes in SCS perception arise from both changes in future time perspective and from emotional self-regulation to develop optimal conceptions of career success, given the worker's age, context, and developmental deadlines, which influence the career goal selection and engagement process. Our analysis provides two key contributions to the career success literature. First, we show that SCS perceptions can change over the course of a career and that SCS perceptions can follow five shift types. Second, we show how the motivational theory of life-span development [13], future time perspective [17], and workrelated motives [18] can enhance our understanding of the patterns in SCS perceptions over the course of a career by considering how, by motivational self-regulation and the time perspective, workers optimize their goal striving through career success perceptions.

\subsection{Limitations and Directions for Future Research}

The present study has some limitations that provide opportunities for future research. A limitation that is important to note is that we studied SCS retrospectively, based on the narratives that our respondents created about their lives. Human memory is prone to biases [40], and future studies would do well to validate the changes in SCS using multiple measurements over the course of careers. A second limitation can be found in the sampling strategy, which was mostly convenience-based. While we made an effort to recruit a diverse sample with respect to gender, race, and career stage, our sample is not fully representative of the Dutch workforce. However, we can argue that the sample size and variation allow for a sufficient basis for our findings. A third limitation is that we interviewed respondents from all three career phases. Even though this allowed us to have early career respondents review their early career experiences, mid-career respondents review their early- and mid-career experiences, and late-career respondents review their entire careers, we interviewed respondents from different generations, which might lead to structural differences in career goal perceptions. In addition, it is important to note that the volume of early-career respondents was as big as the mid- and late-career respondents combined, suggesting an overrepresentation of early-career respondents in the study. 
Future research on the temporal development of SCS perceptions could consider experimenting with multiple career anchors at the same time to enable a comparison of the relative importance of SCS aspects, instead of only focusing on one primary SCS aspect. Our study shows how SCS perceptions can change in terms of the ideal SCS aspect per career phase, but future research could seek to compare the relative importance of SCS aspects over time, perhaps finding clusters of SCS aspects that can be grouped for their underlying characteristics. This could allow for further defining and refining our understanding of the temporal nature of SCS.

\section{Conclusions}

Our findings show the developmental patterns of SCS perceptions over the course of a career. The motivational theory of life-span development [13], socio-emotional selectivity theory [17], and work-related motives [18] provide key explanations for the mechanisms behind these developmental patterns and therefore show how career success literature can transform SCS from a static to a dynamic outcome that evolves over the course of a career.

Author Contributions: Conceptualization: L.H., J.A., O.S. and S.K.; Data curation: L.H.; Formal Analysis: L.H.; Funding acquisition: L.H. and J.A.; Investigation: L.H.; Methodology: L.H.; Project administration: L.H.; Visualization: L.H.; Writing—original draft: L.H.; Writing—review and editing: L.H., J.A., O.S. and S.K. All authors have read and agreed to the published version of the manuscript.

Funding: This research was funded by Stichting Blik op Werk.

Institutional Review Board Statement: The study was conducted according to the guidelines of the Declaration of Helsinki, and approved by the Research Ethical Review Board of the School of Business and Economics, Vrije Universiteit Amsterdam (protocol code SBE7/5/2021LHS247).

Informed Consent Statement: Informed consent was obtained from all subjects involved in the study.

Data Availability Statement: The data presented in this study are available on request from the corresponding author.

Conflicts of Interest: The authors declare no conflict of interest. The funders had no role in the design of the study; in the collection, analyses, or interpretation of data; in the writing of the manuscript, or in the decision to publish the results.

\section{Appendix A Protocol Questions}

1. [The interviewer shows the SCS aspects and scores them with the respondent.]

2. Denote pivotal moments and key transitional periods from your career in the timeline below. You may use crosses or arrows. [Respondent creates career timeline]. Per pivotal moment and key transitional period:

- Describe your own influence in this career moment/period.

- Describe the influence of your environment (e.g., peers) in this career moment/period.

- How content are you with the outcome of this career moment/period?

3. Did your definition of career success change over the course of your career?

- When did these changes occur on your career timeline?

- If so, why did your definition of career success change? 


\section{Appendix B Overview of SCS Aspects, Descriptions, and Example Items}

\begin{tabular}{|c|c|c|}
\hline SCS Aspects & Description & $\begin{array}{l}\text { Example Items: } \\
\text { I Feel My Career is Successful } \\
\text { When. }\end{array}$ \\
\hline 1 Autonomy & $\begin{array}{l}\text { personal ownership and } \\
\text { accomplishments, carrying } \\
\text { responsibility for } \\
\text { self-nurtured projects }\end{array}$ & $\begin{array}{l}\text { I have developed and been } \\
\text { responsible for my own projects / } \\
\ldots \text { I have felt as though I am in } \\
\text { charge of my own career. }\end{array}$ \\
\hline 2 Personal development & $\begin{array}{l}\text { personal growth and } \\
\text { acquiring abilities; acquiring } \\
\text { knowledge and skills }\end{array}$ & $\begin{array}{l}\text { I have expanded my skillsets to } \\
\text { perform better }\end{array}$ \\
\hline 3 Influence & $\begin{array}{l}\text { taking pride in seeing the } \\
\text { effects of personal influence }\end{array}$ & $\begin{array}{l}\text { decisions that I have made have } \\
\text { impacted my organization }\end{array}$ \\
\hline 4 Service to others & $\begin{array}{l}\text { service to others, to be able to } \\
\text { give }\end{array}$ & $\begin{array}{l}\text { I believe my work has made a } \\
\text { difference }\end{array}$ \\
\hline 5 Work-life balance & $\begin{array}{l}\text { achieving balance between } \\
\text { work and non-work } \\
\text { commitments }\end{array}$ & $\begin{array}{l}\text { I have been able to be a good } \\
\text { employee while maintaining } \\
\text { quality non-work relationships }\end{array}$ \\
\hline 6 Quality work & $\begin{array}{l}\text { taking pride in work } \\
\text { outcomes }\end{array}$ & $\begin{array}{l}\text { I am proud of the quality of the } \\
\text { work I have produced }\end{array}$ \\
\hline 7 Recognition & external affirmation & $\begin{array}{l}\text { I have been recognized for my } \\
\text { contributions }\end{array}$ \\
\hline 8 Career satisfaction & $\begin{array}{l}\text { positive affect on overall } \\
\text { career experiences }\end{array}$ & my career is personally satisfying \\
\hline 9 Financial security & $\begin{array}{l}\text { being able to provide the basic } \\
\text { necessities for living } \\
\text { progressive financial }\end{array}$ & $\begin{array}{l}\text { I have been able to provide the } \\
\text { basic necessities for living }\end{array}$ \\
\hline 10 Financial success & $\begin{array}{l}\text { accomplishments; being able } \\
\text { to successively make more } \\
\text { money over the course of the } \\
\text { career }\end{array}$ & $\begin{array}{l}\text { I have been able to progressively } \\
\text { make more money }\end{array}$ \\
\hline 11 Positive relationships & $\begin{array}{l}\text { high-quality work-related } \\
\text { relationships }\end{array}$ & $\begin{array}{l}\text { I get along well with my } \\
\text { colleagues }\end{array}$ \\
\hline
\end{tabular}

\section{References}

1. Arthur, M.B.; Hall, D.T.; Lawrence, B.S. Handbook of Career Theory; Cambridge University Press: Cambridge, UK, 1989.

2. Super, E.D.; Jordaan, J.P. Career development theory. Br. J. Guid. Couns. 1973, 1, 3-6. [CrossRef]

3. Levinson, D.J. The Seasons of a Man's Life; Random House Digital, Inc.: New York, NY, USA, 1978.

4. Mainiero, L.A.; Sullivan, S.E. Kaleidoscope careers: An alternate explanation for the "opt-out "revolution. Acad. Manag. Perspect. 2005, 19, 106-123. [CrossRef]

5. Arthur, M.B.; Khapova, S.; Wilderom, C.P.M. Career success in a boundaryless career world. J. Organ. Behav. 2005, 26, 177-202. [CrossRef]

6. Spurk, D.; Hirschi, A.; Dries, N. Antecedents and Outcomes of Objective versus Subjective Career Success: Competing Perspectives and Future Directions. J. Manag. 2019, 45, 35-69. [CrossRef]

7. Gunz, H.P.; Heslin, P.A. Reconceptualizing career success. J. Organ. Behav. 2005, 26, 105-111. [CrossRef]

8. Ng, T.W.H.; Eby, L.T.; Sorensen, K.L.; Feldman, D.C. Predictors of Objective and Subjective Career Success: A Meta-Analysis. Pers. Psychol. 2005, 58, 367-408. [CrossRef]

9. Shockley, K.M.; Ureksoy, H.; Rodopman, O.B.; Poteat, L.F.; Dullaghan, T.R. Development of a new scale to measure subjective career success: A mixed-methods study. J. Organ. Behav. 2016, 37, 128-153. [CrossRef]

10. Akkermans, J.; Tims, M. Crafting your career: How career competencies relate to career success via job crafting. Appl. Psychol. 2017, 66, 168-195. [CrossRef]

11. Wille, B.; De Fruyt, F.; Feys, M. Big Five Traits and Intrinsic Success in the New Career Era: A 15-Year Longitudinal Study on Employability and Work-Family Conflict. Appl. Psychol. 2012, 62, 124-156. [CrossRef]

12. Akkermans, J.; Kubasch, S. \#Trending topics in careers: A review and future research agenda. Career Dev. Int. 2017, 22, 586-627. [CrossRef]

13. Heckhausen, J.; Wrosch, C.; Schulz, R. A motivational theory of life-span development. Psychol. Rev. 2010, 117, 32-60. [CrossRef] [PubMed]

14. Schein, E.H. How career anchors hold executives to their career paths. Personnel 1975, 52, 11-24. 
15. Heslin, P.A. Conceptualizing and evaluating career success. J. Organ. Behav. 2005, 26, 113-136. [CrossRef]

16. Mayrhofer, W. Career success across the globe: Insights from the 5C project. Organ. Dyn. 2016, 45, 197-205.

17. Carstensen, L.L.; Isaacowitz, D.M.; Charles, S.T. Taking time seriously: A theory of socioemotional selectivity. Am. Psychol. 1999, 54, 165. [CrossRef]

18. Kooij, D.T.A.M.; De Lange, A.H.; Jansen, P.G.W.; Kanfer, R.; Dikkers, J.S.E. Age and work-related motives: Results of a metaanalysis. J. Organ. Behav. 2011, 32, 197-225. [CrossRef]

19. Hughes, E.C. Men and Their Work; Free Press: Glen Coe, Scotland, 1958.

20. Abele, A.E.; Spurk, D.; Volmer, J. The construct of career success: Measurement issues and an empirical example. J. Labour Mark. Res. 2011, 43, 195-206. [CrossRef]

21. Abele, A.E.; Hagmaier, T.; Spurk, D. Does Career Success Make You Happy? The Mediating Role of Multiple Subjective Success Evaluations. J. Happiness Stud. 2016, 17, 1615-1633. [CrossRef]

22. Brentlinger, W.H.; Thorndike, E.L.; Bregman, E.O.; Lorge, I.; Metcalfe, Z.F.; Robinson, E.E.; Woodyard, E. Prediction of Vocational Success. Am. J. Psychol. 1935, 47, 529. [CrossRef]

23. Schein, E.H. Career anchors revisited: Implications for career development in the 21st century. Acad. Manag. Perspect. 1996, 10, 80-88. [CrossRef]

24. Carstensen, L.L.; Fung, H.H.-L.; Charles, S.T. Socioemotional Selectivity Theory and the Regulation of Emotion in the Second Half of Life. Motiv. Emot. 2003, 27, 103-123. [CrossRef]

25. Lysova, E.I.; Allan, B.A.; Dik, B.J.; Duffy, R.D.; Steger, M.F. Fostering meaningful work in organizations: A multi-level review and integration. J. Vocat. Behav. 2019, 110, 374-389. [CrossRef]

26. Lips-Wiersma, M.; Wright, S. Measuring the meaning of meaningful work: Development and validation of the Comprehensive Meaningful Work Scale (CMWS). Group Organ. Manag. 2012, 37, 655-685. [CrossRef]

27. Niks, I.M. Balance at Work: Discovering Dynamics in the Demand-Induced Strain Compensation Recovery (DISC-R) Model; Technische Universiteit Eindhoven: Eindhoven, The Netherlands, 2015.

28. Greenhaus, J.H.; Parasuraman, S.; Wormley, W.M. Effects of Race on Organizational Experiences, Job Performance Evaluations, and Career Outcomes. Acad. Manag. J. 1990, 33, 64-86. [CrossRef]

29. Smale, A.; Bagdadli, S.; Cotton, R.; Russo, S.D.; Dickmann, M.; Dysvik, A.; Gianecchini, M.; Kaše, R.; Lazarova, M.; Reichel, A.; et al. Proactive career behaviors and subjective career success: The moderating role of national culture. J. Organ. Behav. 2019, 40, 105-122. [CrossRef]

30. Heckhausen, J.; Wrosch, C.; Schulz, R. Agency and Motivation in Adulthood and Old Age. Annu. Rev. Psychol. 2019, 70, 191-217. [CrossRef] [PubMed]

31. Kooij, D.T.A.M.; Zacher, H.; Wang, M.; Heckhausen, J. Successful aging at work: A process model to guide future research and practice. Ind. Organ. Psychol. 2020, 13, 345-365. [CrossRef]

32. Heckhausen, J.; Schulz, R. The primacy of primary control is a human universal: A reply to Gould's (1999) critique of the life-span theory of control. Psychol. Rev. 1999, 106, 605-609. [CrossRef]

33. Heckhausen, J.; Schulz, R. A life-span theory of control. Psychol. Rev. 1995, 102, 284. [CrossRef] [PubMed]

34. Schulz, R.; Heckhausen, J. A life span model of successful aging. Am. Psychol. 1996, 51, 702-714. [CrossRef]

35. Creswell, J.W.; Poth, C.N. Qualitative Inquiry and Research Design: Choosing Among Five Approaches; Sage Publications: Newbury Park, CA, USA, 2016.

36. Clark-Ibáñez, M. Framing the Social World with Photo-Elicitation Interviews. Am. Behav. Sci. 2004, 47, 1507-1527. [CrossRef]

37. Harper, D. Talking about pictures: A case for photo elicitation. Vis. Stud. 2002, 17, 13-26. [CrossRef]

38. Bedeian, A.G. The measurement and conceptualization of career stages. J. Career Dev. 1991, 17, 153-166. [CrossRef]

39. Pogson, E.C.; Cober, A.B.; Doverspike, D.; Rogers, J.R. Differences in self-reported work ethic across three career stages. J. Vocat. Behav. 2003, 62, 189-201. [CrossRef]

40. Hintzman, D.L. Research Strategy in the Study of Memory: Fads, Fallacies, and the Search for the "Coordinates of Truth. " Perspect. Psychol. Sci. 2011, 6, 253-271. [CrossRef] [PubMed]

41. Erikson, E.H. Life History and the Historical Movement; Norton: New York, NY, USA, 1975.

42. Goodson, I. The Story of Life History: Origins of the Life History Method in Sociology. Identit 2001, 1, 129-142. [CrossRef]

43. Gehman, J.; Glaser, V.; Eisenhardt, K.M.; Gioia, D.; Langley, A.; Corley, K.G. Finding Theory-Method Fit: A Comparison of Three Qualitative Approaches to Theory Building. J. Manag. Inq. 2018, 27, 284-300. [CrossRef]

44. Gephart, R.P., Jr. Qualitative research and the Academy of Management Journal; Academy of Management Briarcliff Manor: New York, NY, USA, 2004.

45. Gioia, D.A.; Corley, K.G.; Hamilton, A.L. Seeking qualitative rigor in inductive research: Notes on the Gioia methodology. Organ. Res. Methods 2013, 16, 15-31. [CrossRef]

46. Ketokivi, M.; Mantere, S. Two strategies for inductive reasoning in organizational research. Acad. Manag. Rev. 2010, 35, 315-333.

47. Lee, T.W.; Lee, T. Using Qualitative Methods in Organizational Research; Sage Publications: Thousand Oaks, CA, USA, 1999.

48. Lee, T.W.; Mitchell, T.R.; Sablynski, C.J. Qualitative Research in Organizational and Vocational Psychology, 1979-1980. J. Vocat. Behav. 1999, 55, 161-187. [CrossRef]

49. Friese, S. Qualitative Data Analysis with ATLAS; Sage Publications: Thousand Oaks, CA, USA, 2019.

50. Strauss, A.; Corbin, J. Basics of Qualitative Research; Sage Publications: Thousand Oaks, CA, USA, 1990. 
51. Langley, A. Strategies for theorizing from process data. Acad. Manag. Rev. 1999, 24, 691-710. [CrossRef]

52. McAdams, D.P.; Hart, H.M.; Maruna, S. The Anatomy of Generativity, in Generativity and Adult Development: How and Why We Care for the Next Generation; McAdams, D.P., De St. Aubin, E., Eds.; American Psychological Association: Washington, DC, USA, 1998; pp. 7-43.

53. Ashton, M.C.; Lee, K. Age trends in HEXACO-PI-R self-reports. J. Res. Pers. 2016, 64, 102-111. [CrossRef]

54. Lee, K.; Ashton, M.C. Psychopathy, Machiavellianism, and Narcissism in the Five-Factor Model and the HEXACO model of personality structure. Pers. Individ. Differ. 2005, 38, 1571-1582. [CrossRef]

55. Kooij, D.; Van De Voorde, K. How changes in subjective general health predict future time perspective, and development and generativity motives over the lifespan. J. Occup. Organ. Psychol. 2011, 84, 228-247. [CrossRef]

56. Carstensen, L.L. The Influence of a Sense of Time on Human Development. Science 2006, 312, 1913-1915. [CrossRef] [PubMed]

57. Kanfer, R.; Ackerman, P.L. Aging, adult development, and work motivation. Acad. Manag. Rev. 2004, 29, 440-458. [CrossRef]

58. Brandstätter, V.; Schüler, J. Action crisis and cost-benefit thinking: A cognitive analysis of a goal-disengagement phase. J. Exp. Soc. Psychol. 2013, 49, 543-553. [CrossRef]

59. Wrosch, C.; Scheier, M.F.; Miller, G.E.; Schulz, R.; Carver, C. Adaptive Self-Regulation of Unattainable Goals: Goal Disengagement, Goal Reengagement, and Subjective Well-Being. Pers. Soc. Psychol. Bull. 2003, 29, 1494-1508. [CrossRef] 